\title{
Mitochondria Synthesize Melatonin to Ameliorate Its Function and Improve Mice Oocyte's Quality under in Vitro Conditions
}

\author{
Changjiu He ${ }^{\dagger}$, Jing Wang ${ }^{\dagger}$, Zhenzhen Zhang, Minghui Yang, Yu Li, Xiuzhi Tian, Teng Ma, \\ Jingli Tao, Kuanfeng Zhu, Yukun Song, Pengyun Ji and Guoshi Liu *
}

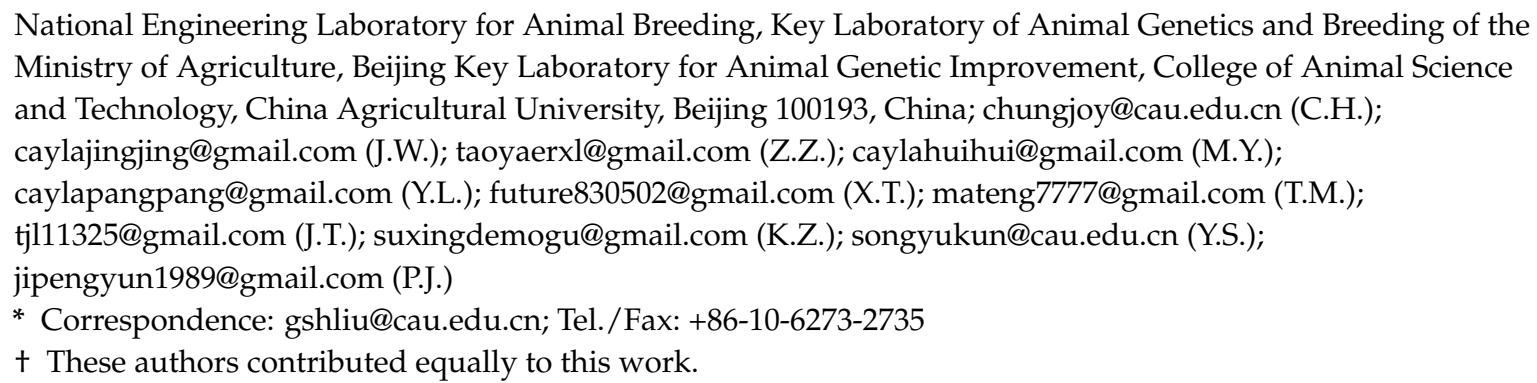

Academic Editor: Manickam Sugumaran

Received: 25 April 2016; Accepted: 2 June 2016; Published: 14 June 2016

\begin{abstract}
The physiology of oocyte in vitro maturation remains elusive. Generally, the oocytes have a very low maturation rate under in vitro conditions. In the current study, we found that melatonin promotes the maturation of oocytes in which mitochondria play a pivotal role. It was identified that; (1) mitochondria are the major sites for melatonin synthesis in oocytes and they synthesize large amounts of melatonin during their maturation; (2) melatonin improves mitochondrial function by increased mtDNA copy, mitochondrial membrane potential $\left(\Delta \Psi_{\mathrm{m}}\right)$ and mitochondrial distribution and ATP production in oocytes; (3) the meiotic spindle assembly is enhanced; (4) melatonin reduces ROS production and inhibits 8-oxodG formation, thereby protecting potential DNA mutation from oxidative damage. As a result, melatonin improves the quality of oocytes, significantly accelerates the developmental ability of IVF embryo. The results provide novel knowledge on the physiology of oocyte's maturation, especially under in vitro conditions.
\end{abstract}

Keywords: antioxidant; melatonin; mitochondria; oocyte; SNAT

\section{Introduction}

Female fertility is mainly determined by the quality of oocytes which are susceptible to multifaceted factors such as environment stressors, availabilities of essential nutrients, etc. [1,2]. Maintaining a normal maturation process is critical for obtaining oocytes of high-quality. Oocyte maturation is a highly coordinated process involving both nuclear and cytoplasmic events, which are composed of both nuclear and cytoplasmic maturations [3,4]. These events include nuclear membrane breakdown and dissolution (GVBD), spindle assembly, epigenetic programming, mitochondrial accumulation and distribution, and reactive oxygen species (ROS) reduction [2]. A spectrum of genes also selectively participate in the process of oocyte maturation. The representative genes include EGF-like protein that mediates LH signaling [5], GDF9 and BMP15 which directly involve energy metabolism [6,7], NPPC/NPR2 signaling which maintain meiosis arrest [8,9], Mos/MAPK-signal cascades and $\mathrm{Cyclin}_{2}$ which involves in meiotic progression and cell cycle control [10]. A newly-found oocyte-derived protein, meiosis arrest female1 (MARF1), has an important function in controlling meiosis, cytoplasmic development, and maintenance of genomic integrity [11,12]. Notably, the 
processes of both oocyte maturation and ovulation are usually comparable to an inflammatory response which is accompanied with large amounts ROS generation $[13,14]$. The excessive ROS, if not properly detoxified, would lead to a poor quality of the oocytes under both in vivo and in vitro conditions [15]. Oocytes are more resistant to oxidative stress during ovulation under the in vivo conditions. This may be attributed to the relatively high levels of antioxidants existing in the follicular fluid [16,17]. They serve as a protective means against ovary oxidative stress.

Melatonin ( $\mathrm{N}$-acetyl-5-methoxytryptamine) is a derivative of tryptophan. This molecule is a naturally occurring potent free radical scavenger and a broad-spectrum antioxidant [18]. As a result, the use of melatonin to prevent oxidative stress in cell culture or animal studies has been extensively reported $[19,20]$. In addition to its antioxidant property, melatonin also plays an important role in animal reproduction. In rat, melatonin lowers estradiol level while it enhances progesterone production during early gestation. In mice, melatonin involves pregnant regulation and promotes embryo implantation $[21,22]$. The circadian variations of melatonin in the maternal circulation may regulate the timing of parturition [23]. Melatonin also affects ovarian function. A relatively high level of melatonin was found in human preovulatory follicular fluid [24,25]. This molecule was found to alleviate goat granulosa cells from the harmful effects of heat stress [26]. The actions of melatonin in physiological and pathological processes are usually mediated by its receptors, such as membrane receptors MT1 and MT2 [27]. These receptors were also expressed in the human granulosa cells and enhanced progesterone production $[28,29]$. The SNAT gene (encoding melatonin synthase, also named $A A N A T$ ) expression and melatonin increases progressively in oocytes during follicular development [30]. However, the organelle synthesizing melatonin in oocytes has not been clarified and the actions of melatonin on ovulation are also not fully understood.

In the current research, the subcellular localization of melatonin synthesis in oocyte was investigated. To clarify the mechanisms of melatonin on quality of oocyte and its maturation, the mitochondrial function, energy states, the spindle assembly, the ROS production, DNA oxidative damage and cellular apoptosis of oocytes have been systematically studied.

\section{Results}

\subsection{Oocytes Synthesize Melatonin during Maturation}

It was observed that SNAT existed persistently at all stages of oocyte's maturation. The proteins of both MT1 and MT2, however, were undetectable in oocytes at every stage assayed with immunofluorescence (Figure 1A) or RT-PCR (Figure 1B). Melatonin was detected in the ovary and serum in the animals during the period of oocyte's maturation. Melatonin levels in ovary at 4 and $8 \mathrm{~h}$ after hCG treatment were significantly higher than those in their contemporaneous sera $(135.7 \pm 23.51$ versus $1.01 \pm 0.260$ and $95.7 \pm 17.09$ versus $1.69 \pm 0.850 \mathrm{ng} / \mathrm{g}$, respectively, $p<0.01$ ) (Figure 1C). Meanwhile, melatonin was also detected in the oocyte's cultured medium at 4 or $8 \mathrm{~h}$, which was significantly higher than that in fresh medium $(1.50 \pm 0.150,1.32 \pm 0.056$ versus $0.52 \pm 0.066 \mathrm{ng} / \mathrm{mL}$, respectively, $p<0.01$ ) (Figure 1D).

\subsection{Mitochondria are the Major Sites for Melatonin Synthesis in Oocytes}

The image from Immuno-electron microscope (JEOL Ltd, Hitachi, Tokyo, Japan) showed that SNAT was distributed in mitochondria and cytoplasm (Figure 2A). To further test the ability of mitochondria in melatonin synthesis, we cultured mitochondria in the presence of the SNAT substrate serotonin. Results suggested that melatonin production was higher in serotonin-supplemented mitochondria than in the respective controls after $15 \mathrm{~min}(26.35 \pm 11.980$ versus $1.92 \pm 1.985 \mathrm{ng} / \mathrm{mL})$ and $30 \mathrm{~min}(44.96 \pm 17.16$ versus $1.93 \pm 0.658 \mathrm{ng} / \mathrm{mL}$ ) culture (Figure $2 \mathrm{~B}$ ). 
A

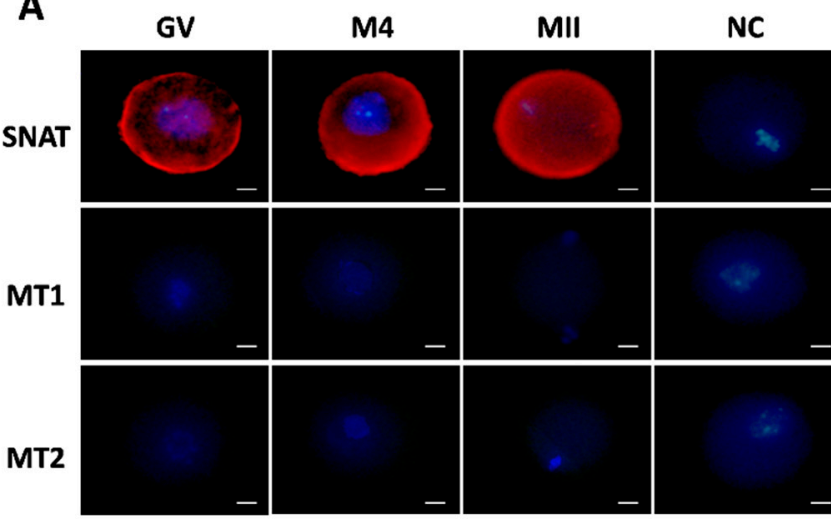

B

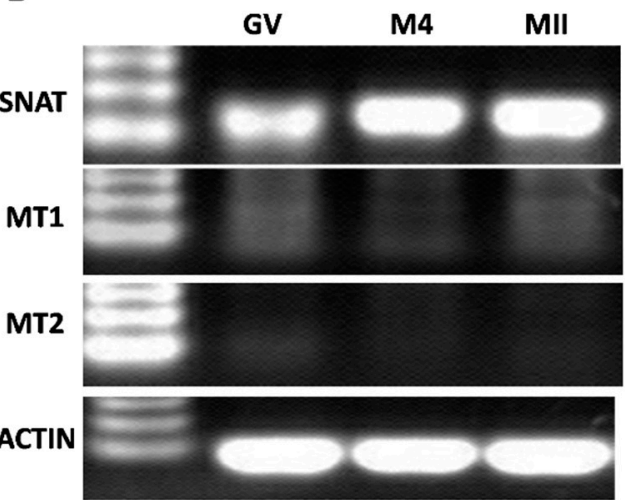

D
C

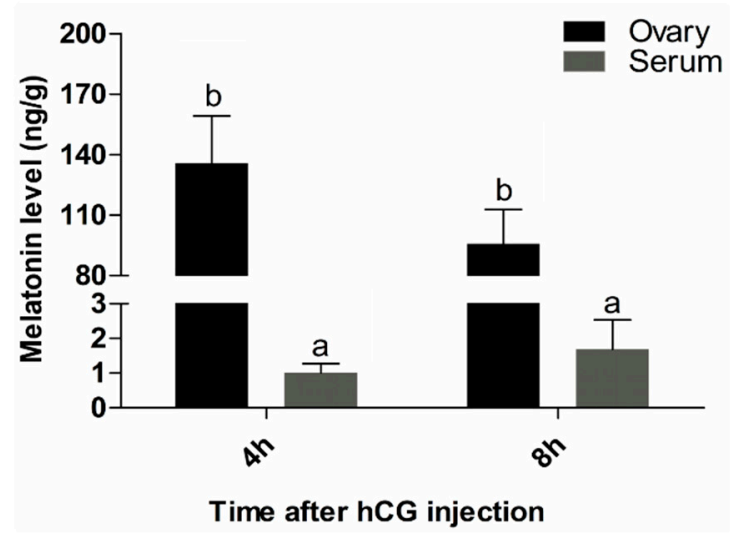

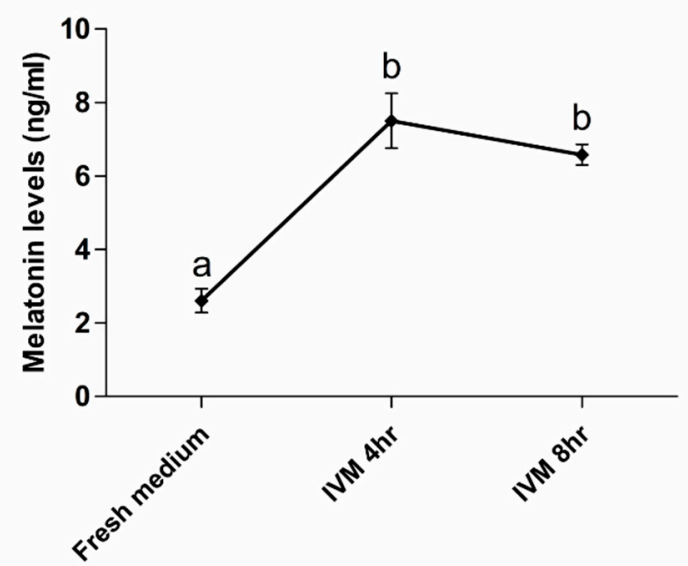

Figure 1. Oocyte synthesis melatonin during its maturation. (A) Assayed with immunofluorescence. Red was SNAT staining. Scale bar $=20 \mu \mathrm{m}$; (B) Assayed with RT-PCR. GV: Germinal Vesicle Stage, M4: $4 \mathrm{~h}$ after hCG injection, MII; Metaphase II of Meiosis, NC: Negative Control; (C) Melatonin levels in ovary homogenate and serum of the animals after hCG injection (mean \pm SEM); (D) Melatonin levels in IVM medium during oocyte culture (mean \pm SEM); the different superscript letters (a-b) represent a significant difference $(p<0.05)$.

A
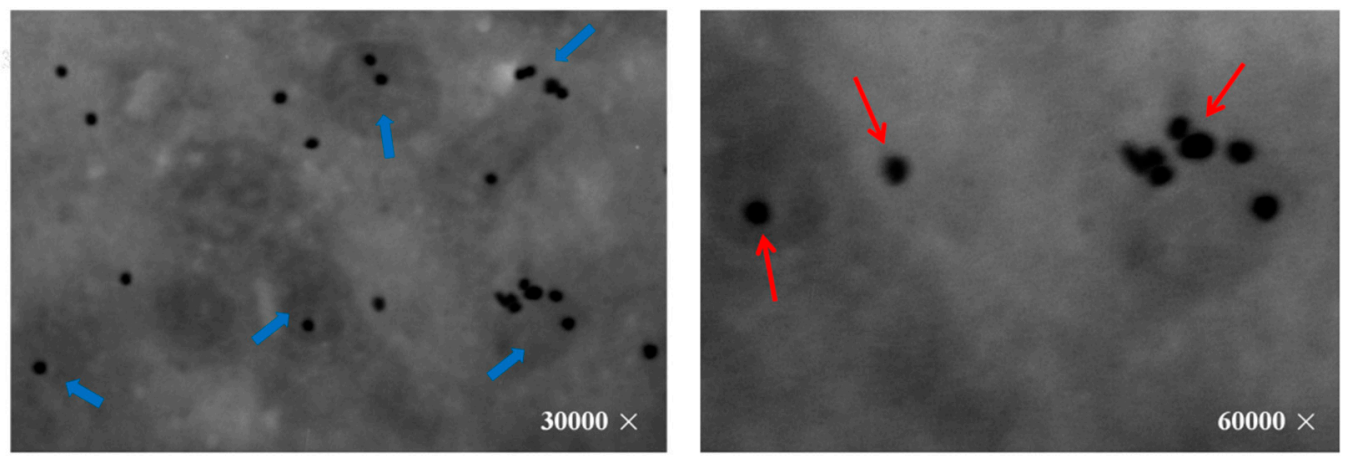

Figure 2. Cont. 
B

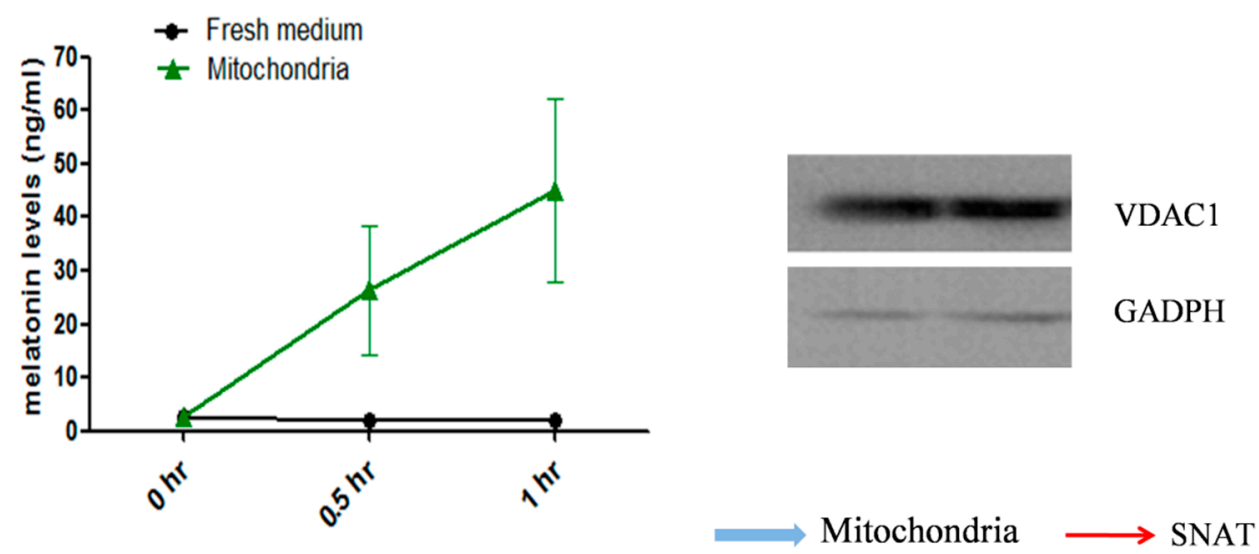

Figure 2. The localization of SNAT in oocyte and melatonin levels in mitochondria culture medium. (A) SNAT distribution sites. The red arrows point to SNAT enzyme (black dot), the blue arrows point to the mitochondria with SNAT localized in; (B) Melatonin concentrations in culture medium during mitochondria culture (mean \pm SEM).

\subsection{Melatonin Improves Oocytes Quality, and Accelerates IVF Embryo Development}

Oocyte maturation medium added with melatonin exhibited a beneficial effect on oocyte's maturation by detecting the developmental potential of IVF embryo in in vitro conditions. Analysis of an additional 1650 oocytes indicated that melatonin did not affect the germinal vesicle breakdown and cleavage rate (Figure $3 \mathrm{~A}, \mathrm{~B}$ ), while the blastocyst rates were significantly higher in melatonin-treated $\left(10^{-5}\right.$ and $\left.10^{-7} \mathrm{M}\right)$ groups than that in control group $(0.31 \pm 0.022$ and $0.32 \pm 0.016$ versus $0.24 \pm 0.013$, $p<0.05)$ (Figure $3 \mathrm{C})$, the cell numbers of blastocyst in melatonin-treated $\left(10^{-7} \mathrm{M}\right)$ group were also significantly higher $(p<0.05)(65.1 \pm 2.55)$ than that in control group $(53.9 \pm 2.49)$ (Figure 3D).
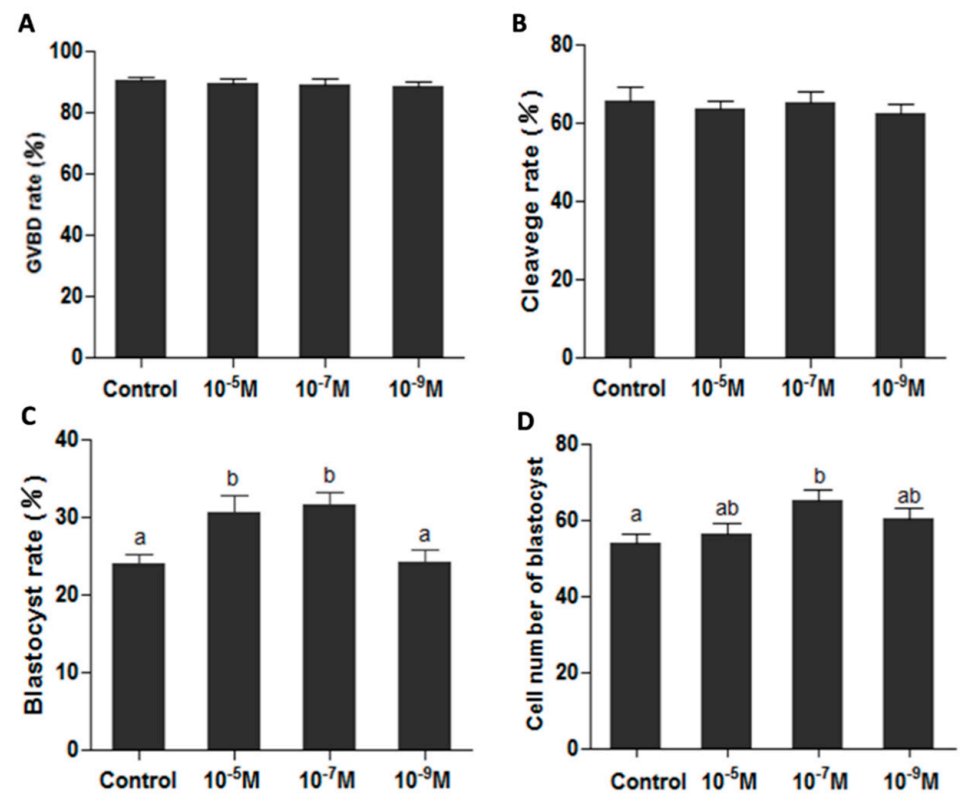

Figure 3. Effects of melatonin on oocyte's maturation and subsequent IVF embryo development. (A) Effect of melatonin on GVBD rate (the percentage of GVBD oocytes); (B) Effects of melatonin on IVF embryonic development; (C) Effects of melatonin on blastocyst rate; (D) Effects of melatonin on the cell numbers of blastocysts (mean \pm SEM of 1650 oocytes). The different superscript letters (a-b) represent a significant difference of these columns $(p<0.05)$. 


\subsection{Melatonin Ameliorates the Function of Mitochondria}

The data from 238 oocytes showed that melatonin treatments $\left(10^{-5}\right.$ and $\left.10^{-7} \mathrm{M}\right)$ significantly improved the mtDNA copy number of MII-stage oocyte $(306,903 \pm 4756$ and 315,690 \pm 4103 versus control 288,123 $\pm 3181, p<0.05, p<0.01$, respectively) (Figure 4A). Analysis of 175 oocytes indicated that melatonin $\left(10^{-7} \mathrm{M}\right)$ decreased the massive clustering distribution rate of mitochondria in MII-stage oocyte $(0.39 \pm 0.050$ versus $0.23 \pm 0.045, p<0.05)$ (Figure $4 \mathrm{~B})$. The $\Delta \Psi_{\mathrm{m}}$ in $10^{-7} \mathrm{M}$ melatonin-treated group was significantly higher than that in control group $(2.67 \pm 0.288$ versus $1.79 \pm 0.166, p<0.05)$ (Figure 4C). ATP level in melatonin-treated oocytes was also higher than that of controls $(1.26 \pm 0.079$ versus $1.06 \pm 0.057 \mathrm{pmol} /$ per oocyte, $p=0.068$ ) (Figure $4 \mathrm{D}$ ).

A
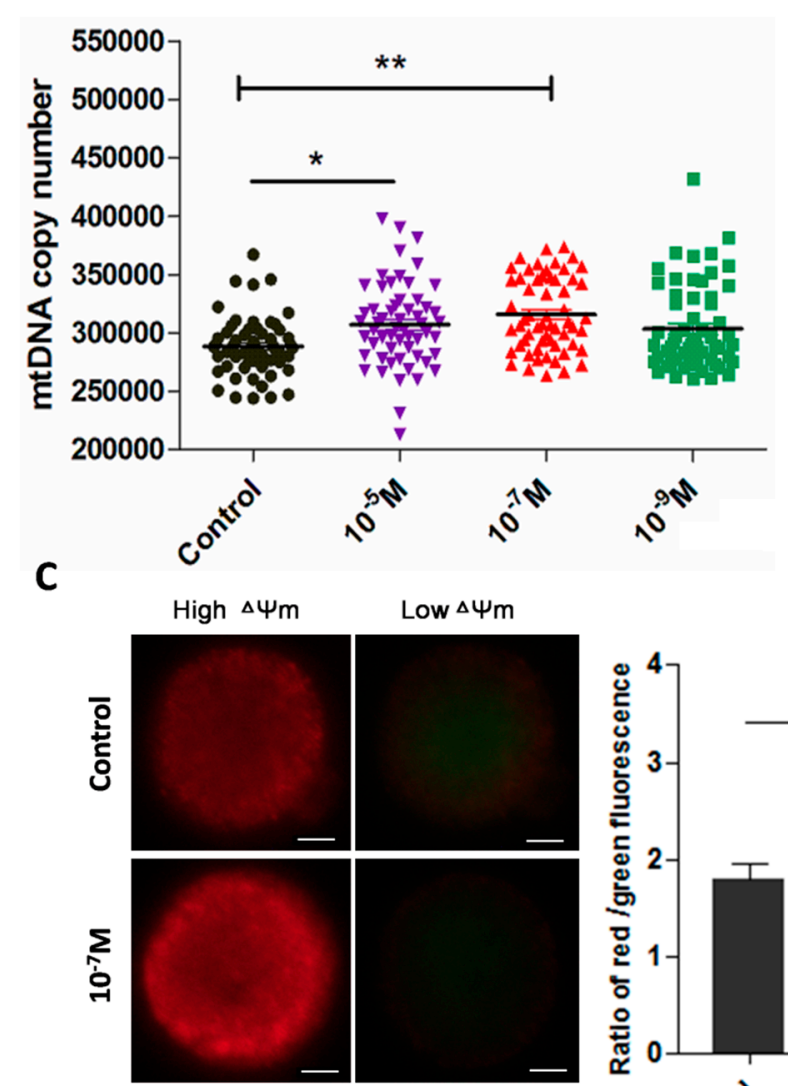

B

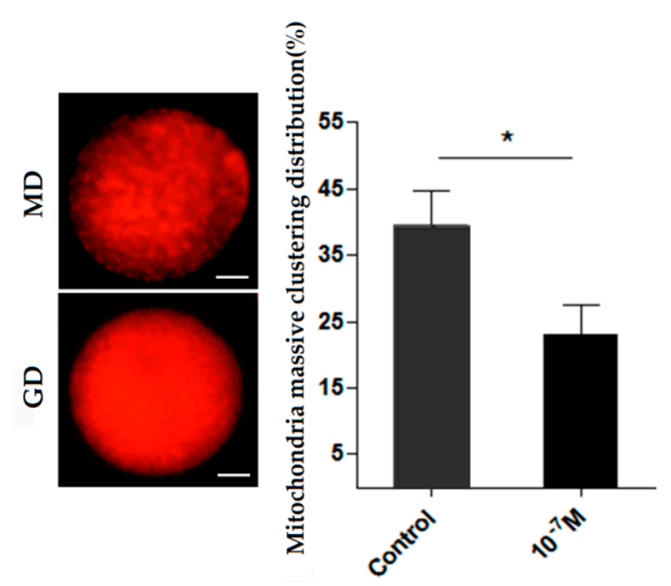

D
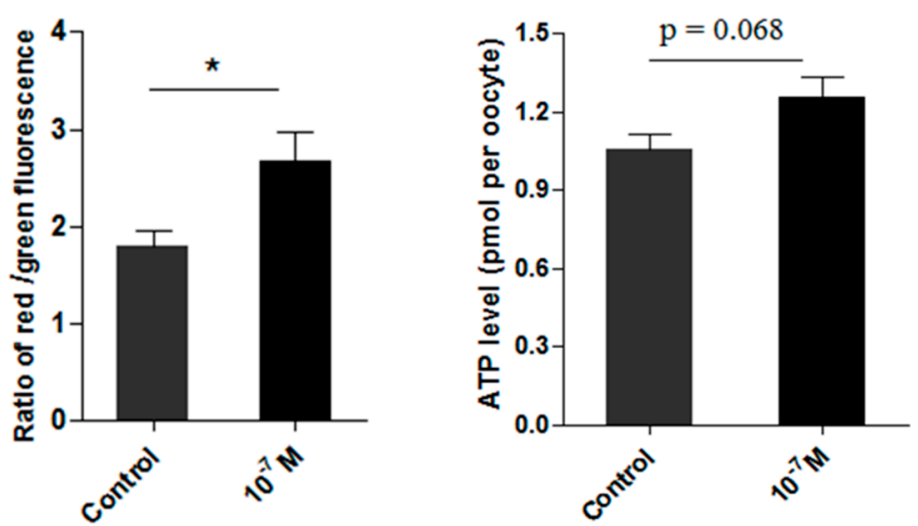

Figure 4. Effects of melatonin on mitochondria function and ATP production in MII-stage oocytes. (A) Cytoplasmic mtDNA copy number in MII-stage oocytes (mean \pm SEM of 238 oocytes); (B) The state of mitochondria distribution (mean \pm SEM of 178 oocytes), GD: granulated distribution; MD: massive clustering distribution. Scale bar $=20 \mu \mathrm{m}$; (C) Mitochondria membrane potential in MII-stage oocytes (mean \pm SEM of 72 oocytes), Scale bar $=20 \mu \mathrm{m}$; (D) Cytoplasmic ATP levels in individual MII oocytes (mean \pm SEM of 120 oocytes). “*” represent significant differences, $p<0.05$; “**” represent significant differences, $p<0.01$.

\subsection{Melatonin Promotes Meiotic Spindle Assembly}

Melatonin also significantly increased the normal spindle rate. The result from 148 oocytes treated with $10^{-7} \mathrm{M}$ melatonin showed the normal rate of meiotic spindles was $76.2 \% \pm 1.94 \%$ which was significantly higher than $67.0 \% \pm 2.22 \%$ in control group $(p<0.05)$ (Figure 5). 

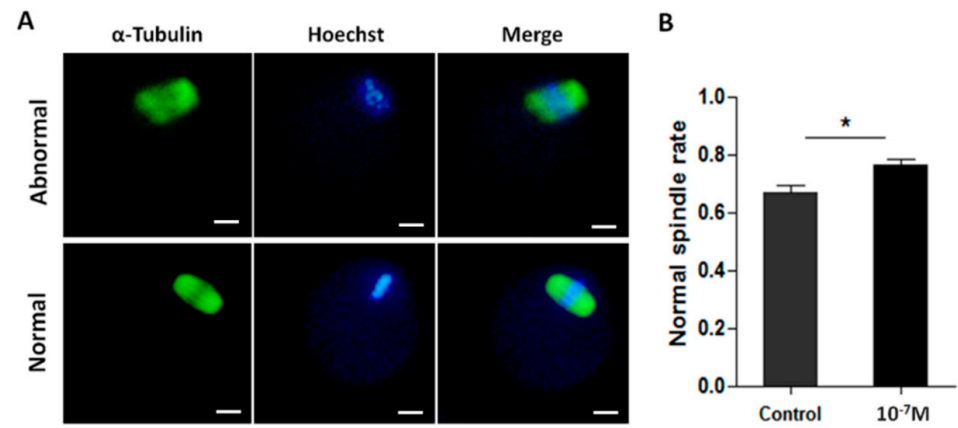

Figure 5. The effects of melatonin on meiotic spindle assembly of MII-stage oocyte. (A) Representative images of normal or abnormal meiotic spindle, Scale bar $=20 \mu \mathrm{m}$; (B) Incidence of normal spindle in melatonin-treated oocytes compared to the controls (mean \pm SEM of 148 oocytes). "** represent significant differences, $p<0.05$.

\subsection{Melatonin Protects Oocyte from Oxidative Damage}

The results showed that the levels of ROS were significantly lower in melatonin-treated oocyte $(0.19 \pm 0.006)$ than that of control $(0.23 \pm 0.007)(p<0.01)$; In contrast, the levels of GSH were significantly higher in melatonin treated oocytes than those in controls $(0.16 \pm 0.003$ versus $0.12 \pm 0.002$, $p<0.01$ ) (Figure 6A). The 8-oxodG production was also reduced by melatonin treatment at $4 \mathrm{~h}$ of in vitro culture $(0.25 \pm 0.031$ versus $0.17 \pm 0.014, p<0.05)$ (Figure $6 \mathrm{~B})$. Finally, the effects of melatonin on apoptosis-associated genes ( $\mathrm{Bcl}-2$, Caspase3, p53) were examined. The gene expression of $\mathrm{Bcl}-2$ was up-regulated by melatonin $(1.50 \pm 0.150)$ compared with control $(0.91 \pm 0.122)(p<0.05)$. In contrast, the gene expression of Caspase3 was down-regulated by melatonin treatment compared to the control $(0.63 \pm 0.059$ versus $1.02 \pm 0.181, p<0.05)$. The expression of $p 53$, however, was not influenced by melatonin (Figure 6C).

A
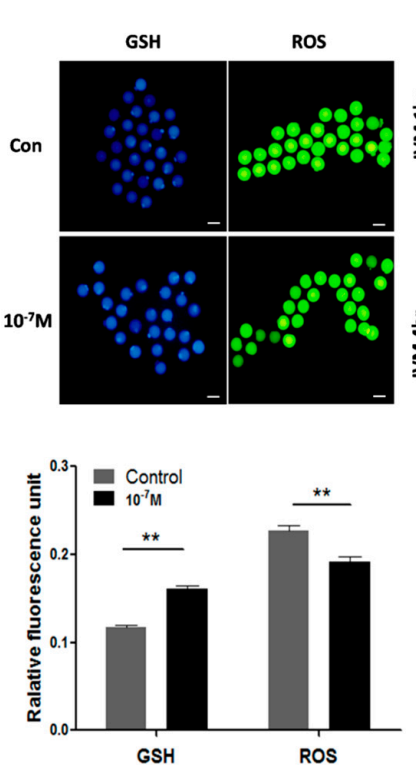
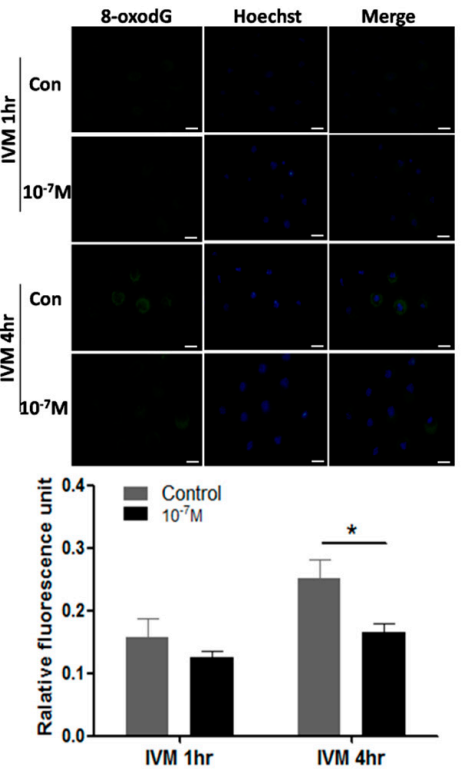

C
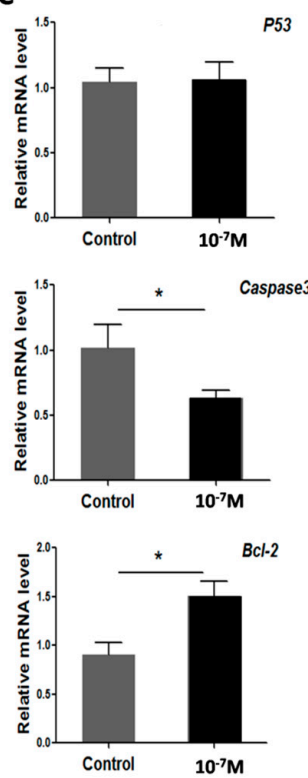

Figure 6. Effects of melatonin on ROS, GSH, 8-oxodG levels as well as apoptosis-associated genes expression in oocyte. (A) Effects of melatonin on levels of GSH and ROS in oocytes (mean \pm SEM of 147oocytes), scale bar $=100 \mu \mathrm{m}$; (B) Effects of melatonin on 8-oxodG levels of oocyte during IVM (mean \pm SEM of 198 oocytes), scale bar $=100 \mu \mathrm{m}$; (C) Effects of melatonin on the expression of apoptosis-associated genes. "** represent significant differences, $p<0.05$; “**" represent significant differences, $p<0.01$. 


\section{Discussion}

In the current study, the mechanisms of melatonin on improving mice oocyte's quality during maturation have been systematically investigated. Previous reports have indicated that melatonin may directly affect ovarian function to serve as a local regulator [31,32]. Melatonin was successively detected in follicular fluids of human [24], porcine [33] and bovine [34] ovaries. In addition, both MT1 and MT2 were identified in human granulosa cells [29]. Therefore, the high levels of melatonin in the follicle may constitute an important protective action for oocyte's maturation. Although high concentrations of melatonin in ovarian follicular fluid have been reported, the original source of melatonin in the fluid is still understood completely. It was reported that, in rat, the highest melatonin levels occurred during the evenings of metestrus and diestrus, while the minimum levels were detected in the evening of estrus [35]. When [3H]-melatonin was injected into cats, this molecule was concentrated in the ovary (ten times higher than that in plasma) [36]. Similarly, in this study, we also observed that the melatonin level was higher in mice preovulation follicles than that in their contemporaneous serum (Figure 1C). Here, we identified that SNAT existed in oocytes during their maturation and the melatonin was also detected in the culture medium of oocytes (Figure 1D). These observations proved that oocytes had the capacity to synthesize melatonin, which was also demonstrated by Sakaguchi K et al. [30]. Based on the findings mentioned above, it appears that the high levels of melatonin in preovulatory follicles are mainly generated by the oocytes and the rest may be extracted from the blood.

To further identify the subcellular site of melatonin synthesis in oocytes, mitochondria were targeted since mitochondria were hypothesized as the original sites of melatonin production [37]. Mitochondria are the main source of energy supply. They also function as a calcium sink as well as the regulators of cellular apoptosis. The mitochondrial dysfunction resulted in extensive ROS generation which is associated with a variety of pathological conditions and diseases [38,39]. Herein, the results indicated that the melatonin synthetic enzyme, $S N A T$, was localized in mitochondria as well as cytoplasm, and the isolated mitochondria retained the capacity to synthesize melatonin (Figure 2). Thus, we claimed that mitochondria are the sites for melatonin synthesis in oocytes during their maturation. In the current study, we failed to detect the classical mitochondria localization signal in the amino acid sequence of SNAT (data were not shown), thus, the mechanism by which SNAT was transported across mitochondria membrane is currently unknown.

It appears that melatonin synthesized by mitochondria in oocytes plays a pivotal role in maintaining the normal physiology of oocytes. To prove it, melatonin was added to culture medium during in vitro oocyte maturation. Melatonin treatment improved the developmental potential of IVF embryo (Figure 3) which reflected an improved quality of oocytes. If these beneficial effects of melatonin on oocyte maturation occurred through its receptor is unknown, since the MT1 and MT2 were undetectable during oocyte maturation using immunofluorescence or RT-PCR (Figure 1A,B). It is also possible that the expression of both receptors is below detection threshold. These results were inconsistent with the observation in the study of bovine oocyte's maturation [40]. This inconsistency may be species specific and, in order to resolve this issue, more studies are required.

Previous studies demonstrated that melatonin preserved the optimal mitochondrial function and homeostasis by reducing mitochondria oxidative stress [41-43]. In the current study, we identified that mitochondria per se synthesize melatonin. It is speculated that the melatonin level has a direct association with mitochondrial function. Indeed, melatonin supplementation significantly increased mtDNA copy number in MII-stage oocyte and influenced the degree of mitochondria granulated clustering (Figure 4A,B). Though the mitochondria distribution is a dynamic process [44], it is an important indicator of oocyte quality. A uniform, granulated distribution of active mitochondria in oocyte maturation and the early embryo specific period is necessary [45-47]. Melatonin also improved mitochondria membrane potential $\left(\Delta \Psi_{\mathrm{m}}\right)$ of oocytes and enhanced their ATP production (Figure $\left.4 \mathrm{C}, \mathrm{D}\right)$ ). High $\Delta \Psi_{\mathrm{m}}$ is a precondition for ATP production [48]. In oocytes, both the mitochondria content and ATP levels are positively associated with the developmental competence of oocytes, that is, they promote the cytoplasmic maturation of oocytes and their IVF embryos' development $[49,50]$. The 
discovery that mitochondria produce melatonin to ameliorate its function has important biological consequences. Mitochondria are the major source of ROS production and they need additional protection from oxidative stress. Melatonin is a potent, naturally occurring antioxidant. Its de novo production in mitochondria may provide the on-site protection.

The spindle abnormalities and chromosomal misalignment are increased during in vitro oocyte maturation, which might be a result of insufficient ATP production of cells cultured in vitro since the meiotic spindle assembly and maintenance require ATP [51]. Melatonin supplementation in IVM medium significantly reduced these abnormalities (Figure 5A). That melatonin increased ATP production (Figure 4) may contribute to oocyte spindle assembly.

Another obstacle for oocyte maturation is over-produced ROS. The extensive ROS production jeopardizes the quality of oocytes and, therefore, hinders the oocyte's maturation process and causes apoptosis. A relatively high level of ROS was detected in oocytes under their in vitro maturation (Figure 6A). To combat the negative effects of the excessive ROS and promote the oocyte's maturation, antioxidants are frequently used in the in vitro culture system [52,53]. In this study, we found that melatonin addition to the culture medium significantly reduced the ROS and increased GSH level of the oocytes (Figure 6A). It is very possible that melatonin not only reduced ROS level via its direct ROS-scavenging action but also by improving mitochondrial function (Figure 4) which alleviates the ROS generation and increases the production of GSH [54]. In addition, melatonin was shown to reduce the levels of 8-oxodG which is a negative consequence of ROS (Figure 6B). As the major oxidative product of free nucleotide, 8-oxodGTP may be incorporated into DNA and cause mutation [55]. If the mutation is long-lasting, a negative effect on the oocyte quality and subsequent embryo development will be predicted. Furthermore, the apoptosis of oocytes may result from a poor mitochondrial function and excess ROS under in vitro conditions [56]. The apoptosis was triggered by Caspase3, which is activated by cytochrome $\mathrm{c}$ release from mitochondria. $\mathrm{Bcl}-2 \mathrm{can}$ interfere with cytochrome $\mathrm{c}$ release and therefore inhibit Caspase3 activation [57,58]. In the current study, melatonin down-regulates Caspase3 and up-regulates $\mathrm{Bcl}-2$ at the same time (Figure $6 \mathrm{C}$ ), which protects oocyte from apoptosis.

In conclusion, this probably is the first study to identify the subcellular site of melatonin synthesis in oocytes. It was revealed that mitochondria are the organelles responsible for melatonin synthesis in oocytes. This discovery has significant biological implications. Melatonin de novo production in mitochondria may provide on-site protection. This was indicated by the improved mtDNA copy number, decreased clustering distribution of mitochondria, increased mitochondria membrane potential and enhanced ATP production in oocytes treated with melatonin. Therefore, it promotes meiotic spindle assembly and GSH production, reduces the ROS level, 8-oxodG and may inhibit oocyte apoptosis. These factors contribute to the beneficial effects of melatonin in improving the oocyte's quality and, ultimately, the developmental ability of IVF embryo (Figure 7). The discoveries also provide a theoretical basis for application of melatonin in human test-tube baby technology.

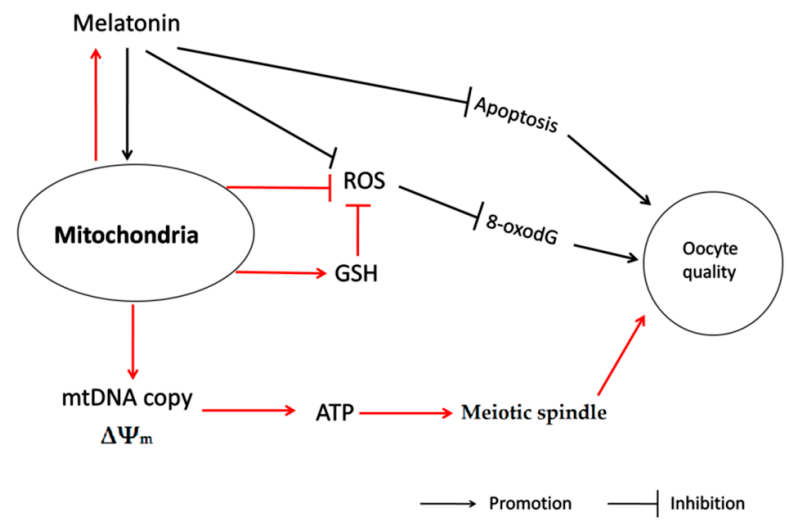

Figure 7. The action pathway connecting the beneficial effect of melatonin on oocyte quality during maturation. 


\section{Materials and Methods}

\subsection{Chemicals}

Pregnant mare serum gonadotropin (PMSG) and human chorionic gonadotrophin (hCG) were obtained from Ningbo Hormone Products Co., Ltd. (Zhejiang, China). Melatonin, Sodium Pyruvate, BSA, Fetuin, Hyaluronidase, Penicillin and Streptomycin were purchased from Sigma-Aldrich (St. Louis, MO, USA). MEMa medium was purchased from Gibco (Carlsbad, CA, USA).

\subsection{Animal Treatment}

Three to five week old CD-1 mice (melatonin-proficient) were purchased from Vital River Laboratories Co., Ltd. (Beijing, China). Mice were housed under controlled conditions with temperature $\left(22-26^{\circ} \mathrm{C}\right.$ ) and a light/dark cycle 12/12 h. Animals were allowed to access to food and water ad libitum. PMSG (10 I.U.) was injected into mice abdomen in advance of $44-46 \mathrm{~h}$ to stimulate oocyte growth to sufficient size, and then hCG (10 I.U.) was injected to trigger oocyte maturation and ovulation. All animal studies have been approved by the animal care committees of China Agricultural University.

\subsection{Analyses of Melatonin Receptors and Rate-Limiting Enzyme for Melatonin Synthesis}

Mice were superovulated with an intraperitoneal injection of PMSG followed by hCG as mentioned above. Oocytes were collected at 0,4 and $16 \mathrm{~h}$ respectively after hCG injection by puncturing the ovaries or oviducts with $1 \mathrm{~mL}$ disposable syringes. Retrieved oocytes were denuded with incubation in $100 \mathrm{IU} / \mathrm{mL}$ of hyaluronidase and then washed with PBS containing $0.5 \%$ BSA. The zona pellucida was removed via rapidly incubation in the acidified Tyrode's solution (Irvine Scientific, Santa Ana, CA, USA). Thereafter, the oocytes were fixed and permeated in $4.0 \%$ neutral-buffered paraformaldehyde containing $0.3 \%$ Triton $\mathrm{X}-100$ at $37^{\circ} \mathrm{C}$ for $15 \mathrm{~min}$. Nonspecific binding was blocked using PBS supplemented with $0.5 \%$ BSA, $0.1 \%$ Triton $\mathrm{X}-100$, and $5 \%$ fatal bovine serum (FBS) at $37^{\circ} \mathrm{C}$ for $1 \mathrm{~h}$ and then antibodies of MT1, MT2 and SNAT (MT1, MT2, 1:100 dilution; SNAT: 1:300 dilution with PBS containing 0.5\% BSA, and 5\% FBS, Santa Cruz Bio Inc., Delaware Ave Santa Cruz, CA, USA) were added, respectively, and incubated at $4{ }^{\circ} \mathrm{C}$ for overnight. Oocytes were then washed three times with PBS containing 0.5\% BSA and 0.01\% Triton X-100 (15 min per wash) and incubated with donkey anti-goat IgG-FITC (1:100 dilution, Santa Cruz Bio Inc., Santa Cruz, CA, USA) goat anti-rabbit conjugated Alexa Fluor-568 (Life Technologies, Carlsbad, MA, USA) at $37^{\circ} \mathrm{C}$ for $1 \mathrm{~h}$. After washing, the cell nucleus was counterstained with Hoechst (Vector Laboratories) and analyzed by epifluorescence microscope (TE300; Nikon, Tokyo, Japan).

\subsection{Immuno-Electron Microscopic Identification of Melatonin Synthesizing Sites}

PMSG (10 I.U.) was injected into mice abdomen in advance of $46 \mathrm{~h}$ to stimulate oocyte growing to sufficient size. The ovaries were collected from the abdomen cavity and they were fixed for $48 \mathrm{~h}$ in $2.5 \%$ glutaraldehyde. After washing, these ovaries were further dehydrated with a graded series of ethanol, xylene and, then, were embedded in epoxy resin. The follicles with the typical GV-stage oocytes were sectioned $(100 \mathrm{~nm})$ and placed on nickel grids and incubated in blocking solution $(0.05 \%$ glycine in PBS) for $10 \mathrm{~min}$. Then, the specimens were incubated with the SNAT primary antibody at $4{ }^{\circ} \mathrm{C}$ for 12-16 $\mathrm{h}$ and followed by incubated with anti-rabbit IgG (whole molecule)-gold-conjugated secondary antibody (1:20 dilution, Sigma-Aldrich, St. Louis, MO, USA) for another 2 h. After washing, these specimens were counterstained with $7 \%$ uranyl acetate, and washed again with distilled water. Images were acquired using a JEM-2200FS microscope (JEOL Ltd., Hitachi, Tokyo, Japan). 


\subsection{Melatonin Assay with High Performance Liquid Chromatography (HPLC)}

To measure the melatonin levels in ovary and serum during the course of oocyte maturation, mice were anesthetized with pentobarbital sodium by intraperitoneal injection at $4,8 \mathrm{~h}$ after hCG injection. Blood was collected from caudal vein and centrifuged at $3000 \mathrm{r}$ for $10 \mathrm{~min}$ to obtain the serum. The ovary samples of mice were weighed and homogenized immediately in $1 \mathrm{~mL}$ methyl alcohol and centrifuged at $12,000 \mathrm{rpm}$ for $10 \mathrm{~min}$ at $4{ }^{\circ} \mathrm{C}$. The supernatant was collected for melatonin assay. All procedures were performed under ice bath. To detecting the melatonin content in maturation medium, GV-stage oocytes were acquired by puncturing the ovary at $44-46 \mathrm{~h}$ after PMSG injection and denuded with hyaluronidase. For each group, 100 oocytes were cultured in MEMa medium supplemented with $10^{-4} \mathrm{M}$ serotonin (Sigma-Aldrich St. Louis, MO, USA), PMSG (1 I.U./mL), hCG (2 I.U. $/ \mathrm{mL}), 0.3 \%$ BSA, Fetuin $(1 \mathrm{mg} / \mathrm{mL})$, Sodium Pyruvate $(20 \mathrm{mM})$, Penicillin $(75 \mu \mathrm{g} / \mathrm{mL})$ and Streptomycin $(50 \mu \mathrm{g} / \mathrm{mL})$. The $100 \mu \mathrm{L}$ of maturation medium was collected at $4 \mathrm{~h}, 8 \mathrm{~h}$ of the culture, respectively, for melatonin assay. All sample preparation and HPLC detection of melatonin were performed as previously reported [59]. The experiments were repeated at least 6 times.

\subsection{Mitochondrial Isolation and Detection of Melatonin in Culture Medium}

GV-stage oocytes were collected (See above), then divided into two groups (Melatonin-treated, Control) and cultured for $16 \mathrm{~h}$ in maturation medium. Then, mitochondrion were isolated using mitochondria isolation kit (Beyotime, Jiangsu, China) following the manufacturers' instructions. The isolated mitochondria were then cultured in PBS supplemented with $10^{-4} \mathrm{M}$ serotonin (the substrate of melatonin biosynthesis) at $37^{\circ} \mathrm{C}$ for 15 and $30 \mathrm{~min}$ to test their melatonin-biosynthetic capacity. Melatonin in PBS was extracted and measured as mentioned previously. The experiments were independently repeated six times.

\subsection{Western Blot Analysis}

Following mitochondria isolation, its purity was verified by Western blot. VDAC1 and GADPH were selected as mitochondrial marker and cytoplasm marker, respectively. In brief, mitochondria samples were lysed in laemmli sample buffer (Bio-Rad, Hercules, CA, USA). Proteins were then separated by SDS-PAGE (12\% acrylamide running gel) and transferred to a nitrocellulose membrane (BioTraceNT, Pall Corporation, Ann Arbor, MI, USA). Nonspecific binding to the membrane was blocked with $5 \%$ nonfat milk in Tris (10 mM), pH 7.5, $\mathrm{NaCl}(150 \mathrm{mM})$, and $0.1 \%$ Tween 20 at $37^{\circ} \mathrm{C}$ for $1 \mathrm{~h}$. Membranes were then incubated with primary antibodies (VDAC1 and GADPH (Abcam Inc, Cambridge, MA, USA) (1:4000 dilution, ab154856, ab128915, respectively)) at $4{ }^{\circ} \mathrm{C}$, overnight, followed by incubation with horseradish peroxidase-conjugated secondary antibody (rabbit: 1:5000 dilution, ZB-2301, from ZSGB-Bio, Beijing, China) at $37^{\circ} \mathrm{C}$ for another $1 \mathrm{~h}$. Analysis was performed with enhanced chemiluminescence detection reagents (Applygen Technologies Inc., Beijing, China) and X-Omat BT film (HuaxingBio Inc., Beijing, China), according to the manufacturers' instructions.

\subsection{Oocyte in Vitro Maturation (IVM), in Vitro Fertilization (IVF) and Embryo Culture}

GV-stage oocytes were collected by puncturing the ovary at $44-46 \mathrm{~h}$ after PMSG injection and then they were cultured in $60-\mu \mathrm{L}$ of maturation medium containing $0,10^{-9}, 10^{-7}, 10^{-5} \mathrm{M}$ melatonin, respectively, at an incubator $\left(5 \% \mathrm{CO}_{2}, 37^{\circ} \mathrm{C}\right)$ for $16 \mathrm{~h}$. After germinal vesicle breakdown (GVBD), the matured oocytes were denuded with hyaluronidase (Sigma-Aldrich, St. Louis, MO, USA). The percentage of GVBD oocytes (rate of GVBD) was recorded. Each cauda epididymidis was removed from adult male mice and the sperm were collected by gently squeezing the tissue with tweezers and placed into HTF medium (Sage Biopharma, Bedminster, NJ, USA) for capacitation at $37^{\circ} \mathrm{C}$ for $1 \mathrm{~h}$. The denuded oocytes were then incubated with sperms in HTF medium for $5 \mathrm{~h}$. Pronuclei were washed to diminish the sperms and they were transferred into $60-\mu \mathrm{L}$ KSOM medium (Millipore, Billerica, MA, USA) supplemented with 10\% FBS for later development. Microscopic examination 
was then performed to monitor the development rates of both 2-cell and blastocyst. The cell numbers of blastocysts were assessed by Hoechst staining and the cells were mounted on a clean glass slide covering with a coverslip and examined using an epifluorescence microscope.

\subsection{Detection of mtDNA Copy Number by $q P C R$}

The mitochondria-encoded NADH dehydrogenase subunit 5 gene (MT-ND5) was selected as an index to determine the mtDNA copy numbers. MT-ND5 gene was amplified by PCR, then PCR products were extracted using the Tiangen gel extraction kit (Tiangen Biotech, Beijing, China), and cloned into the pEASYTM-T5 Zero Cloning vector (TransGen Biotech, Beijing, China) to obtain the recombinant plasmids. A single MII oocyte was added to a PCR tube with $5 \mu \mathrm{L}$ of lysis buffer $(50 \mathrm{mM}$ Tris, $0.1 \mathrm{mM}$ EDTA, $0.5 \%$ Tween- 20 and $100 \mu \mathrm{g} / \mathrm{mL}$ Proteinase $\mathrm{K}$ ), incubated at $55^{\circ} \mathrm{C}$ for $30 \mathrm{~min}$ to lyse oocyte, and $95^{\circ} \mathrm{C}$ for $10 \mathrm{~min}$ to inactivate Proteinase $\mathrm{K}$. Then, amplification was performed by LightCycler 480 SYBR Green I Master Mix (Roche Diagnostics, Indianapolis, IN, USA) on LightCycler 480 II PCR machine (Roche Applied Science, Mannheim, Germany). Standard curves were determined using recombinant plasmids, which were serially diluted by $10^{1}-10^{5}$ times. The real-time qPCR reactions consisted of SYBR Green $(10 \mu \mathrm{L})$, forward and reverse primers $(30 \mu \mathrm{M})$, template $(5 \mu \mathrm{L})$ and $\mathrm{ddH}_{2} \mathrm{O}$ was added up to a total volume of $20 \mu \mathrm{L}$. The procedure was as follows: $95{ }^{\circ} \mathrm{C}$ for $10 \mathrm{~min} ; 35$ cycles of $95^{\circ} \mathrm{C}$ for $10 \mathrm{~s}$ and $60^{\circ} \mathrm{C}$ for $10 \mathrm{~s}$. For each sample, the mtDNA copy numbers are calculated using the threshold cycle number $\left(C_{t}\right)$ and corrected from the standard curve. MT-ND5 primer sequences are listed in Table 1 . The experiment was independently repeated 3 times.

Table 1. Primers for RT-PCR and qRT-PCR.

\begin{tabular}{clc}
\hline Genes & \multicolumn{1}{c}{ Primer Sequence(5'-3') } & $\mathbf{T}_{\mathbf{m}}\left({ }^{\circ} \mathbf{C}\right)$ \\
\hline \multirow{2}{*}{ - Actin } & $\begin{array}{l}\text { Forward: CCAGCCTTCCTTCTTGGGTAT } \\
\text { Reverse: AGGTCTTTACGGATGTCAACG }\end{array}$ & 60 \\
\hline \multirow{2}{*}{53} & $\begin{array}{l}\text { Forward: TGAGGTTCGTGTTTGTGCCTGC } \\
\text { Reverse: CCATCAAGTGGTTTTTCTTTTGC }\end{array}$ & 60 \\
\hline \multirow{2}{*}{ Bcl-2 } & $\begin{array}{l}\text { Forward: ACCTGTGGTCCATCTGACCCTC } \\
\text { Reverse: CCAGTTCACCCCATCCCTGA }\end{array}$ & 60 \\
\hline \multirow{2}{*}{ Caspase-3 } & $\begin{array}{l}\text { Forward: CTGGAGAAATTCAAAGGACGGG } \\
\text { Reverse: TGAGCATGGACACAATACACGG }\end{array}$ & 60 \\
\hline \multirow{2}{*}{ MT-ND5 } & $\begin{array}{l}\text { Forward: ATAGCCTGGCAGACGAACAAGACA } \\
\text { Reverse: AATTAGTAGGGCTCAGGCGTTGGT }\end{array}$ & 60 \\
\hline \multirow{2}{*}{ MT1 } & $\begin{array}{l}\text { Forward: CCATTTCATCGTGCCTATG } \\
\text { Reverse: GTAACTAGCCACGAACAGC }\end{array}$ & 58 \\
\hline \multirow{2}{*}{ MT2 } & $\begin{array}{l}\text { Forward: TACATCAGCCTCGTCTGGCTCC } \\
\text { Reverse: TTCCTCGTAGCCTTGGCCTTCC }\end{array}$ & 58 \\
\hline \multirow{2}{*}{ SNAT } & $\begin{array}{l}\text { Forward: TGAACATCAACTCCCTGAAACCT } \\
\text { Reverse: TTCCCGCTCAATCTCAAACG }\end{array}$ & 60 \\
\hline
\end{tabular}

\subsection{Oocytes Mitochondrial Distribution Assay}

MitoTracker Red CMRox (Life Technologies) was used to detect mitochondrial distribution. GV-stage oocytes were collected and divided into two groups $\left(10^{-7} \mathrm{M}\right.$ Melatonin-treated and Control, respectively). Cells were cultured in maturation medium for $16 \mathrm{~h}$. Then, MII-stage oocytes were collected and denuded from the adherence of cumulus cells and they were incubated in M2 (Sigma-Aldrich, St. Louis, MO, USA) medium supplemented with $100 \mathrm{nM}$ dye at $37^{\circ} \mathrm{C}$ for $40 \mathrm{~min}$. Oocytes were then washed and analyzed by epifluorescence microscope (TE300; Nikon, Tokyo, Japan). Oocytes with a uniform granulated distribution of active mitochondria were scored as granulated distribution (GD), the oocytes with a massive clustering distribution of mitochondria were scored as 
massive distribution (MD). The images were observed and scored by three independent persons who are unaware this study. The experiment was independently repeated 3 times.

\subsection{Detection of Mitochondrial Membrane Potential $\left(\Delta \Psi_{m}\right)$ and ATP Levels in Oocytes}

The $\Delta \Psi_{\mathrm{m}}$ of the oocytes was measured using JC-1 (Beyotime, Haimen, Jiangsu, China). JC-1 fluorescence has two emission peaks, with red fluorescence indicating high mitochondrial membrane potential and green fluorescence indicating low mitochondrial membrane potential. Briefly, MII-stage oocytes in each group were exposed to $10 \mu \mathrm{g} / \mathrm{mL}$ of JC- 1 at $37^{\circ} \mathrm{C}$ for $15 \mathrm{~min}$, and then washed with M2 medium to remove surface fluorescence. Fluorescence was observed using an epifluorescence microscope. The distribution of JC-1 dimers with red fluorescence and monomers with green fluorescence were detected using a red filter and green filter of the microscope, respectively. Fluorescence intensity was analyzed using ImageJ software (version 1.40; National Institutes of Health, Bethesda, MD, USA), the ratio of red to green fluorescence was used to analyze $\Delta \Psi_{\mathrm{m}}$. The experiments were independently repeated 3 times.

MII-stage oocytes were washed with PBS-PVA and a group of 10 oocytes were collected for ATP measurement, ATP levels were determined using a commercially available adenosine $5^{\prime}$-triphosphate (ATP) bioluminescent somatic cell assay kit (FLASC, Sigma-Aldrich, St. Louis, MO, USA) according to the manufacturer's instructions. Briefly, oocytes were transferred into a 96-well plate with $45.8 \mu \mathrm{L}$ ATP assay buffer, then $0.2 \mu \mathrm{L}$ ATP probe, $2 \mu \mathrm{L}$ ATP converter and $2 \mu \mathrm{L}$ developer Mix were added. The plate was placed at room temperature for $30 \mathrm{~min}$. ATP levels were measured using a luminometer (Bioluminat Junior, Berthold, Germany). The experiments were independently repeated 6 times.

\subsection{Spindles Analysis}

GV-stage oocytes were collected though puncturing the ovary which stimulated by PMSG, then divided into two groups $\left(10^{-7} \mathrm{M}\right.$ Melatonin-treated, Control) and cultured for $16 \mathrm{~h}$ in maturation medium. MII-stage oocytes' collection and immunofluorescence stain processed as described above. Mouse anti- $\alpha$-tubulin was selected as the primary antibody (1:100 dilution, Santa Cruz Bio Inc., Santa Cruz, CA, USA), goat anti-mouse LgG-FITC was selected as the secondary antibody (1:100 dilution, Santa Cruz Bio Inc., CA, USA). For the spindle analyses, oocytes with barrel-shaped bipolar spindles having distinct and well-organized microtubule fibers, along with tightly aligned chromosomes on the metaphase plate, were scored as normal. The normal spindle rate is the percentage of oocytes with normal spindle. All experiments were independently repeated at least 3 times.

\subsection{Measurement of Reactive Oxygen Species (ROS) and Glutathione (GSH)}

The 2,7-dichlorodihydrofluorescein diacetate (H2DCFDA) (Beyotime, Jiangsu, China) and Cell Tracker Blue CMF2HC Molecular Probes (Invitrogen Inc., Carlsbad, CA, USA) were used to detect intracellular ROS and GSH level, respectively. GV-stage oocytes were collected through puncturing the ovary and divided into two groups $\left(10^{-7} \mathrm{M}\right.$ Melatonin-treated, Control) and cultured for $16 \mathrm{~h}$ in maturation medium. Then, MII-stage oocytes were collected and denuded from adherence of cumulus cells, then they were incubated (in the dark) for $30 \mathrm{~min}$ in M2 medium containing H2DCFDA (10 $\mu \mathrm{M})$ or Cell Tracker Blue $(10 \mu \mathrm{M})$, respectively. The MII-stage oocytes were collected and denuded from the adherence of cumulus cells, and placed in $30 \mu \mathrm{L}$ M2 droplets, and then the fluorescence was observed using an epifluorescence microscope. The fluorescence intensity was analyzed using ImageJ software (version 1.40; National Institutes of Health, Bethesda, MD, USA). The experiments were replicated 6 times.

\subsection{8-oxodG Assay}

GV-stage oocytes were collected by puncturing the ovary, then divided into two groups $\left(10^{-7} \mathrm{M}\right.$ Melatonin-treated, Control) and cultured in maturation medium. Oocytes were then collected and denuded from adherence of cumulus cells at 1, $4 \mathrm{~h}$, respectively, after in vitro maturation and they 
were fixed in pure methanol at $-20{ }^{\circ} \mathrm{C}$ for $20 \mathrm{~min}$. Thereafter, they were incubated in PBS with $0.3 \%$ Triton x-100 for another $15 \mathrm{~min}$. They were blocked with 5\% FBS, 0.5\% BSA in PBS at $37^{\circ} \mathrm{C}$ for $1 \mathrm{~h}$. Oocytes were then incubated with Alexa 488-conjugated avidin (10 $\mu \mathrm{g} / \mathrm{mL})$ (Invitrogen Inc., Carlsbad, CA, USA) in blocking solution at $37^{\circ} \mathrm{C}$ for $1 \mathrm{~h}$. After washing, DNA was counterstained with Hoechst and analyzed by epifluorescence microscope (TE300; Nikon). The fluorescence intensity of 8-oxodG was analyzed using ImageJ software. The experiments were replicated 6 times.

\subsection{Gene Expression Assay with Reverse Transcriptional PCR or Real-Time qPCR}

Oocytes were collected and denuded from the adherent cumulus cells at 0,4 and $16 \mathrm{~h}$, respectively, after hCG injection. The reaction procedure of RT-PCR was as follows: the initial denaturation at $95^{\circ} \mathrm{C}$ for $5 \mathrm{~min}$; denaturation at $95^{\circ} \mathrm{C}$ for $30 \mathrm{~s}$, annealing at $58^{\circ} \mathrm{C}$ for $30 \mathrm{~s}$ and then extension at $72{ }^{\circ} \mathrm{C}$ for $30 \mathrm{~s}$. The above procedures were repeated 35 cycles with a final extension at $72{ }^{\circ} \mathrm{C}$ for $5 \mathrm{~min}$. For qPCR assay, GV-stage oocytes were collected and divided into two groups (10 ${ }^{-7} \mathrm{M}$ Melatonin-treated, Control) and cultured for $16 \mathrm{~h}$ in maturation medium. The amplification was performed by LightCycler 480 SYBR Green I Master Mix (Roche Diagnostics, Indianapolis, IN, USA) on LightCycler 480 II PCR machine (Roche Applied Science, Mannheim, Germany). The real-time qPCR reactions consisted of 1 SYBR Green $(10 \mu \mathrm{L})$, forward and reverse primers $(30 \mu \mathrm{M})$, template $(2 \mu \mathrm{L})$ and $\mathrm{ddH}_{2} \mathrm{O}$ was added up to a total volume of $20 \mu \mathrm{L}$. The procedure was as follows: $95^{\circ} \mathrm{C}$ for $10 \mathrm{~min} ; 35$ cycles of $95^{\circ} \mathrm{C}$ for $10 \mathrm{~s}$ and $60-62^{\circ} \mathrm{C}$ for 8-15 s; melting curve from 65 to $95^{\circ} \mathrm{C}$, increasing in an increment of $0.5^{\circ} \mathrm{C}$ every $5 \mathrm{~s}$. Normalization was performed using the housekeeping gene Actin as control. Primer sequences are listed in Table 1. The experiments were replicated at least 3 times.

\subsection{Statistics Analysis}

Data are expressed as mean \pm S.E.M. Statistical analyses were used the univariate analysis of variance (ANOVA) with the aid of SPSS 19.0 statistical software followed by the Student $t$-test. $p<0.05$ was considered statistically significant, and $p<0.01$ was considered statistically highly significant.

Acknowledgments: This research was supported by the National Natural Science Foundation of China (31172177), National Program on Key Basic Research Project (973 Program) (2014CD138505) and other national grant as follows: 2014ZX08008-002B.

Author Contributions: Guoshi Liu, Changjiu He and Jing Wang conceived and designed the experiments; Changjiu He, Jing Wang, Zhenzhen Zhang, Minghui Yang and Yu Li performed the experiments; Xiuzhi Tian, Teng Ma and Jingli Tao analyzed the data; Kuanfeng Zhu, Yukun Song and Pengyun Ji contributed materials; Changjiu He wrote the paper.

Conflicts of Interest: The authors declare no conflict of interest.

\section{References}

1. Gilchrist, R.B.; Thompson, J.G. Oocyte maturation: Emerging concepts and technologies to improve developmental potential in vitro. Theriogenology 2007, 67, 6-15. [CrossRef] [PubMed]

2. Krisher, R.L. In vivo and in vitro environmental effects on mammalian oocyte quality. Annu. Rev. Anim. Biosci. 2013, 1, 393-417. [CrossRef] [PubMed]

3. Li, R.; Albertini, D.F. The road to maturation: Somatic cell interaction and self-organization of the mammalian oocyte. Nat. Rev. Mol. Cell Biol. 2013, 14, 141-152. [CrossRef] [PubMed]

4. Albertini, D.F. Regulation of meiotic maturation in the mammalian oocyte: Inteplay between exogenous cues and the microtubule cytoskeleton. Bioessays 1992, 14, 97-103. [CrossRef] [PubMed]

5. Park, J.; Su, Y.; Ariga, M.; Law, E.; Jin, S.C.; Conti, M. EGF-like growth factors as mediators of LH action in the ovulatory follicle. Science 2004, 303, 682-684. [CrossRef] [PubMed]

6. Su, Y.Q.; Wu, X.; O’Brien, M.J.; Pendola, F.L.; Denegre, J.N.; Matzuk, M.M.; Eppig, J.J. Synergistic roles of BMP15 and GDF9 in the development and function of the oocyte-cumulus cell complex in mice: Genetic evidence for an oocyte-granulosa cell regulatory loop. Dev. Biol. 2004, 276, 64-73. [CrossRef] [PubMed] 
7. Yeo, C.X.; Gilchrist, R.B.; Thompson, J.G.; Lane, M. Exogenous growth differentiation factor 9 in oocyte maturation media enhances subsequent embryo development and fetal viability in mice. Hum. Reprod. 2008, 23, 67-73. [CrossRef] [PubMed]

8. Zhang, M.; Su, Y.; Sugiura, K.; Xia, G.; Eppig, J.J. Granulosa cell ligand NPPC and its receptor NPR2 maintain meiotic arrest in mouse oocytes. Science 2010, 330, 366-369. [CrossRef] [PubMed]

9. Robinson, J.W.; Zhang, M.; Shuhaibar, L.C.; Norris, R.P.; Geerts, A.; Wunder, F.; Eppig, J.J.; Potter, L.R.; Jaffe, L.A. Luteinizing hormone reduces the activity of the NPR2 guanylyl cyclase in mouse ovarian follicles, contributing to the cyclic GMP decrease that promotes resumption of meiosis in oocytes. Dev. Biol. 2012, 366, 308-316. [CrossRef] [PubMed]

10. Wickramasinghe, D.; Albertini, D.F. Cell cycle control during mammalian oogenesis. Curr. Top. Dev. Biol. 1993, 28, 126-126.

11. Su, Y.Q.; Sugiura, K.; Sun, F.; Pendola, J.K.; Cox, G.A.; Handel, M.A.; Schimenti, J.C.; Eppig, J.J. MARF1 regulates essential oogenic processes in mice. Science 2012, 335, 1496-1499. [CrossRef] [PubMed]

12. Su, Y.Q.; Sun, F.; Handel, M.A.; Schimenti, J.C.; Eppig, J.J. Meiosis arrest female 1 (MARF1) has nuage-like function in mammalian oocytes. Proc. Natl. Acad. Sci. USA 2012, 109, 18653-18660. [CrossRef] [PubMed]

13. Espey, L.L. Current status of the hypothesis that mammalian ovulation is comparable to an inflammatory reaction. Biol. Reprod. 1994, 50, 233-238. [CrossRef] [PubMed]

14. Richards, J.S.; Russell, D.L.; Ochsner, S.; Espey, L.L. Ovulation: New dimensions and new regulators of the inflammatory-like response. Annu. Rev. Physiol. 2002, 64, 69-92. [CrossRef] [PubMed]

15. Behrman, H.R.; Kodaman, P.H.; Preston, S.L.; Gao, S. Oxidative stress and the ovary. J. Soc. Gynecol. Investig. 2001, 8, S40-S42. [CrossRef]

16. Carbone, M.C.; Tatone, C.; Delle Monache, S.; Marci, R.; Caserta, D.; Colonna, R.; Amicarelli, F. Antioxidant enzymatic defences in human follicular fluid: Characterization and age-dependent changes. Mol. Hum. Reprod. 2003, 9, 639-643. [CrossRef] [PubMed]

17. Revelli, A.; Delle Piane, L.; Casano, S.; Molinari, E.; Massobrio, M.; Rinaudo, P. Follicular fluid content and oocyte quality: From single biochemical markers to metabolomics. Reprod. Biol. Endocrinol. 2009, 7, 4330-4337. [CrossRef] [PubMed]

18. Manchester, L.C.; Coto Montes, A.; Boga, J.A.; Andersen, L.P.H.; Zhou, Z.; Galano, A.; Vriend, J.; Tan, D.X.; Reiter, R.J. Melatonin: An ancient molecule that makes oxygen metabolically tolerable. J. Pineal. Res. 2015, 59, 403-419. [CrossRef] [PubMed]

19. Reiter, R.J.; Tan, D.X.; Maldonado, M.D. Melatonin as an antioxidant: Physiology versus pharmacology. J. Pineal. Res. 2005, 39, 215-216. [CrossRef] [PubMed]

20. Cruz, M.H.C.; Leal, C.L.V.; da Cruz, J.F.; Tan, D.; Reiter, R.J. Role of melatonin on production and preservation of gametes and embryos: A brief review. Anim. Reprod. Sci. 2014, 145, 150-160. [CrossRef] [PubMed]

21. Dair, E.L.; Simoes, R.S.; Simões, M.J.; Romeu, L.R.G.; Oliveira-Filho, R.M.; Haidar, M.A.; Baracat, E.C.; Soares, J.M. Effects of melatonin on the endometrial morphology and embryo implantation in rats. Fertil. Steril. 2008, 89, 1299-1305. [CrossRef] [PubMed]

22. He, C.J.; Wang, J.; Li, Y.; Zhu, K.F.; Xu, Z.Y.; Song, Y.L.; Song, Y.K.; Liu, G.S. Melatonin-related genes expressed in the mouse uterus during early gestation promote embryo implantation. J. Pineal. Res. 2015, 58, 300-309. [CrossRef] [PubMed]

23. Yellon, S.M.; Longo, L.D. Melatonin rhythms in fetal and maternal circulation during pregnancy in sheep. Am. J. Physiol.-Endoc. Metab. 1987, 252, 799-802.

24. Brzezinski, A.; Seibel, M.M.; Lynch, H.J.; Deng, M.; Wurtman, R.J. Melatonin in human preovulatory follicular fluid. J. Clin. Endocr. Metab. 1987, 64, 865-867. [CrossRef] [PubMed]

25. Nakamura, Y.; Tamura, H.; Takayama, H.; Kato, H. Increased endogenous level of melatonin in preovulatory human follicles does not directly influence progesterone production. Fertil. Steril. 2003, 80, 1012-1016. [CrossRef]

26. Fu, Y.; He, C.J.; Ji, P.Y.; Zhuo, Z.Y.; Tian, X.Z.; Wang, F.; Tan, D.X.; Liu, G.S. Effects of melatonin on the proliferation and apoptosis of Sheep Granulosa Cells under Thermal Stress. Int. J. Mol. Sci. 2014, 15, 21090-21104. [CrossRef] [PubMed]

27. Slominski, R.M.; Reiter, R.J.; Schlabritz-Loutsevitch, N.; Ostrom, R.S.; Slominski, A.T. Melatonin membrane receptors in peripheral tissues: Distribution and functions. Mol. Cell. Endocrinol. 2012, 351, 152-166. [CrossRef] [PubMed] 
28. Yie, S.M.; Niles, L.P.; Younglai, E.V. Melatonin receptors on human granulosa cell membranes. J. Clin. Endocr. Metab. 1995, 80, 1747-1749. [PubMed]

29. Woo, M.M.; Tai, C.; Kang, S.K.; Nathwani, P.S.; Pang, S.F.; Leung, P.C. Direct action of melatonin in human granulosa-luteal cells. J. Clin. Endocr. Metab. 2001, 86, 4789-4797. [CrossRef] [PubMed]

30. Sakaguchi, K.; Itoh, M.T.; Takahashi, N.; Tarumi, W.; Ishizuka, B. The rat oocyte synthesises melatonin. Reprod. Fertil. Dev. 2013, 25, 674-682. [CrossRef] [PubMed]

31. Tamura, H.; Nakamura, Y.; Korkmaz, A.; Manchester, L.C.; Tan, D.; Sugino, N.; Reiter, R.J. Melatonin and the ovary: Physiological and pathophysiological implications. Fertil. Steril. 2009, 92, 328-343. [CrossRef] [PubMed]

32. Tamura, H.; Takasaki, A.; Taketani, T.; Tanabe, M.; Lee, L.; Tamura, I.; Maekawa, R.; Aasada, H.; Yamagata, Y.; Sugino, N. Melatonin and female reproduction. Obstet. Gynaecol. Res. 2014, 40, 1-11. [CrossRef] [PubMed]

33. Shi, J.M.; Tian, X.Z.; Zhou, G.B.; Wang, L.; Gao, C.; Zhu, S.E.; Zeng, S.M.; Tian, J.H.; Liu, G.S. Melatonin exists in porcine follicular fluid and improves in vitro maturation and parthenogenetic development of porcine oocytes. J. Pineal Res. 2009, 47, 318-323. [CrossRef] [PubMed]

34. El-Raey, M.; Geshi, M.; Somfai, T.; Kaneda, M.; Hirako, M.; Abdel Ghaffar, A.E.; Sosa, G.A.; El Roos, M.E.; Nagai, T. Evidence of melatonin synthesis in the cumulus oocyte complexes and its role in enhancing oocyte maturation in vitro in cattle. Mol. Reprod. Dev. 2011, 78, 250-262. [CrossRef] [PubMed]

35. Ozaki, Y.; Wurtman, R.J.; Alonso, R.; Lynch, H.J. Melatonin secretion decreases during the proestrous stage of the rat estrous cycle. Proc. Natl. Acad. Sci. USA 1978, 75, 531-534. [CrossRef] [PubMed]

36. Wurtman, R.J.; Axelrod, J.; Potter, L.T. The uptake of H3-melatonin in endocrine and nervous tissues and the effects of constant light exposure. J. Pharmacol. Exp. Ther. 1964, 143, 314-318. [PubMed]

37. Tan, D.X.; Manchester, L.C.; Liu, X.; Rosales Corral, S.A.; Acuna Castroviejo, D.; Reiter, R.J. Mitochondria and chloroplasts as the original sites of melatonin synthesis: A hypothesis related to melatonin's primary function and evolution in eukaryotes. J. Pineal Res. 2013, 54, 127-138. [CrossRef] [PubMed]

38. Lin, M.T.; Beal, M.F. Mitochondria dysfunction and oxidative stress in neurodegenerative diseases. Nature 2006, 443, 787-795. [CrossRef] [PubMed]

39. Van Blerkom, J.; Davis, P.; Mathwig, V.; Alexander, S. Domains of high-polarized and low-polarized mitochondria may occurin mouse and human oocytes and early embryos. Hum. Reprod. 2002, 17, 393-406. [CrossRef] [PubMed]

40. Tian, X.Z.; Wang, F.; He, C.J.; Zhang, L.; Tan, D.X.; Reiter, R.J.; Xu, J.; Ji, P.Y.; Liu, G.S. Beneficial effects of melatonin on bovine oocytes maturation: A mechanistic approach. J. Pineal Res. 2014, 57, 239-247. [CrossRef] [PubMed]

41. Jou, M.J.; Peng, T.I.; Yu, P.Z.; Jou, S.B.; Reiter, R.J.; Chen, J.Y.; Wu, H.Y.; Chen, C.C.; Hsu, L.F. Melatonin protects against common deletion of mitochondria DNA-augmented mitochondria oxidative stress and apoptosis. J. Pineal Res. 2007, 43, 389-403. [CrossRef] [PubMed]

42. Ren, L.; Wang, Z.; An, L.; Zhang, Z.; Tan, K.; Miao, K.; Tao, L.; Cheng, L.; Zhang, Z.; Yang, M.; et al. Dynamic comparisons of high-resolution expression profiles highlighting mitochondria-related genes between in vivo and in vitro fertilized early mouse embryos. Hum. Reprod. 2015, 30, 2892-2911. [PubMed]

43. Semak, I.; Naumova, M.; Korik, E.; Terekhovich, V.; Wortsman, J.; Slominski, A. A novel metabolic pathway of melatonin: Oxidation by cytochrome C. Biochemistry 2005, 44, 9300-9307. [CrossRef] [PubMed]

44. Yamochi, T.; Hashimoto, S.; Amo, A.; Goto, H.; Yamanaka, M.; Inoue, M.; Nakaoka, Y.; Morimoto, Y. Mitochondrial dynamics and their intracellular traffic in porcine oocytes. Zygote 2015, 1. [CrossRef] [PubMed]

45. Nagai, S.; Mabuchi, T.; Hirata, S.; Shoda, T.; Kasai, T.; Yokota, S.; Hoshi, K. Correlation of abnormal mitochondrial distribution in mouse oocytes with reduced developmental competence. Tohoku Jexpmed 2006, 210, 137-144. [CrossRef]

46. Brevini, T.A.L.; Cillo, F.; Antonini, S.; Gandolfi, F. Cytoplasmic remodelling and the acquisition of developmental competence in pig oocytes. Anim. Reprod. Sci. 2007, 98, 23-38. [CrossRef] [PubMed]

47. Bavister, B.D.; Squirrell, J.M. Mitochondrial distribution and function in oocytes and early embryos. Hum. Reprod. 2000, 15, 189-198. [CrossRef] [PubMed]

48. Klingenberg, M.; Rottenberg, H. Relation between the gradient of the ATP/ADP ratio and the membrane potential across the mitochondrial membrane. Eur. J. Biochem. 1977, 73, 125-130. [CrossRef] [PubMed] 
49. Selesniemi, K.; Lee, H.; Muhlhauser, A.; Tilly, J.L. Prevention of maternal aging-associated oocyte aneuploidy and meiotic spindle defects in mice by dietary and genetic strategies. Proc. Natl. Acad. Sci. USA 2011, 108, 12319-12324. [CrossRef] [PubMed]

50. Thouas, G.A.; Trounson, A.O.; Wolvetang, E.J.; Jones, G.M. Mitochondria dysfunction in mouse oocytes results in preimplantation embryo arrest in vitro. Biol. Reprod. 2004, 71, 1936-1942. [CrossRef] [PubMed]

51. McNally, F.J. Mechanisms of spindle positioning. J. Cell Biol. 2013, 200, 131-140. [CrossRef] [PubMed]

52. Bormann, C.L.; Ongeri, E.M.; Krisher, R.L. The effect of vitamins during maturation of caprine oocytes on subsequent developmental potential in vitro. Theriogenology 2003, 59, 1373-1380. [CrossRef]

53. Wang, F.; Tian, X.Z.; Zhang, L.; He, C.J.; Ji, P.Y.; Li, Y.; Tan, D.X.; Liu, G.S. Beneficial effect of resveratrol on bovine oocyte maturation and subsequent embryonic development after in vitro fertilization. Fertil. Steril. 2014, 101, 577-586. [CrossRef] [PubMed]

54. García Ruiz, C.; Morales, A.; Colell, A.; Ballesta, A.; Rodés, J.; Kaplowitz, N.; Fernández Checa, J.C. Feeding $S$-adenosyl-L-methionine attenuates both ethanol-induced depletion of mitochondria glutathione and mitochondria dysfunction in periportal and perivenous rat hepatocytes. Hepatology 1995, 21, 207-214. [CrossRef] [PubMed]

55. Gad, H.; Koolmeister, T.; Jemth, A.; Eshtad, S.; Jacques, S.A.; Ström, C.E.; Svensson, L.M.; Schultz, N.; Lundbäck, T.; Einarsdottir, B.O. MTH1 inhibition eradicates cancer by preventing sanitation of the dNTP pool. Nature 2014, 508, 215-221. [CrossRef] [PubMed]

56. Wang, C.; Youle, R.J. The role of mitochondria in apoptosis. Annu. Rev. Genet. 2009, 43, 95-118. [CrossRef] [PubMed]

57. Porter, A.G.; Jänicke, R.U. Emerging roles of Caspase-3 in apoptosis. Cell Death Differ. 1999, 6, 99-104. [CrossRef] [PubMed]

58. Rossé, T.; Olivier, R.; Monney, L.; Rager, M.; Conus, S.; Fellay, I.; Jansen, B.; Borner, C. Bcl-2 prolongs cell survival after Bax-induced release of cytochrome c. Nature 1998, 391, 496-499. [PubMed]

59. Zhao, Y.; Tan, D.X.; Lei, Q.; Chen, H.; Wang, L.; Li, Q.T.; Gao, Y.; Kong, J. Melatonin and its potential biological functions in the fruits of sweet cherry. J. Pineal Res. 2013, 55, 79-88. [CrossRef] [PubMed]

(C) 2016 by the authors; licensee MDPI, Basel, Switzerland. This article is an open access article distributed under the terms and conditions of the Creative Commons Attribution (CC-BY) license (http://creativecommons.org/licenses/by/4.0/). 